\title{
気流に平行に磁力支持された円柱の抵抗係数 Drag coefficients of cylinders magnetically supported in axial flow
}

澤田秀夫 ${ }^{1}$ ，樋口 博 ${ }^{2}$ ，国益徹也 ${ }^{3}$, 須田信一 ${ }^{4}$ Hideo Sawada, Hiroshi Higuchi, Tetsuya Kunimasu, Shinichi Suda

\section{SUMMARY}

Drag coefficient of axial cylinders was measured without any support interference, utilizing JAXA $60 \mathrm{~cm}$ MSBS(Magnetic Suspension and Balance System) at speeds from $20 \mathrm{~m} / \mathrm{s}$ to $35 \mathrm{~m} / \mathrm{s}$. Drag coefficient depended on the fineness ratio of the cylinder but not on the Reynolds number within the range tested $(50,000-100,000$ based on the cylinder diameter). The drag coefficient increased proportionally with the fineness ratio larger than 4.13 , corresponding to the turbulent boundary layer growth downstream of the reattachment line. The present data supersede those of two earlier sources by Hoerner and Eiffel at fineness ratios larger than 4 .

Key words: bluff body aerodynamics, drag, wake, MSBS

1. はじめに

気流に平行に置かれた円柱では細長比が0から2付 近まで大きくなるにつれて抵抗係数 $\left(\mathrm{C}_{\mathrm{D}}\right)$ が減少し, 細 長比 2 から3付近の值を越え, 更に増すと抵抗係数は増 加に転じるデータを記した文献1）と，ほぼ一定值を維持 するという文献2）が見られる。円盤前縁から剥離した 流れの円柱との干渉に注目した研究はあるが ${ }^{3}$, 全抗力 を測定する際，尾部にステイイグを取付ければ，後流と狞イ ングの干渉を生じる。一方，円柱前部にステイグを取付け て後流を計測する場合は円柱前部の抗力への影響を判 定することが困難である。ワ仿てでの支持も角度調整や 乱流擾乱などの問題がある。

磁力支持天秤装置は磁気の力で風洞模型を支持し, 模型に加わる空気力を計測するもので，支持干渉が無
く，円柱の後流と抵抗を同時に計測できる。そこで， 宇宙航空研究開発機構(JAXA)の $60 \mathrm{~cm}$ 磁力支持天秤装 置（60cmMSBS）を用いて，気流に平行に置かれた幾 つかの細長比の円柱抵抗と後流を測定した。（図1参

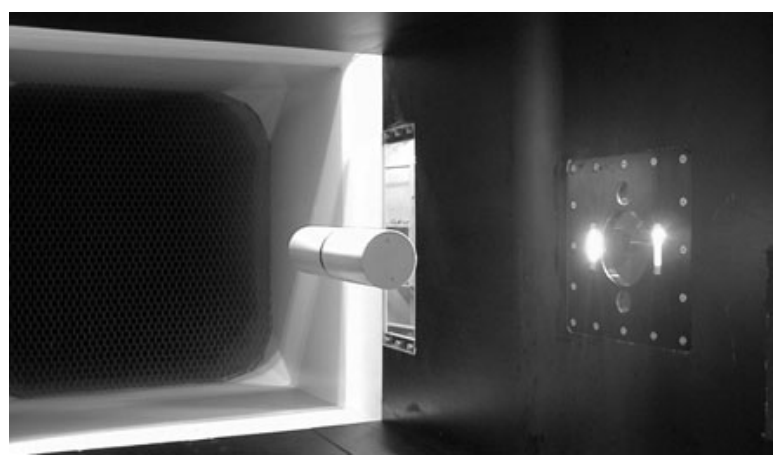

図1 磁力支持中の円柱（直径45mm円柱）

(Figure 1 A magnetically suspended cylinder)

1宇宙航空研究開発機構、総合技術研究本部、空気力学研究 G 先進空力実験 SG 工博 Aerodynamic Research G., the Institute of Space Technology and Aeronautics, Japan Aerospace Exploration Agency, Dr. Eng. 2シラキュース大学機械-航空宇宙生産工学部 教授 Ph. D.

Department of Mechanical, Aerospace, and Manufacturing Engineering, Syracuse University, Professor 3 宇宙航空研究開発機構、総合技術研究本部、空気力学研究 G 先進空力実験 SG

Aerodynamic Research G., the Institute of Space Technology and Aeronautics, Japan Aerospace Exploration Agency 4宇宙航空研究開発機構、総合技術研究本部、空気力学研究 $\mathrm{G}$ 先進空力実験 $\mathrm{SG}$ 工博

Aerodynamic Research G., the Institute of Space Technology and Aeronautics, Japan Aerospace Exploration Agency. Dr. Eng.

(原稿受理 : 平成 16 年 5 月 18 日) 
照）JAXAの磁力支持天秤装置と磁力支持風洞の詳細は 文献4）を参照されたい。

\section{2. 抗力係数測定試験}

\section{1. 円柱模型と風洞気流}

本試験に用いた円柱は2種類で，直径（D） $25 \mathrm{~mm} の 円$ 柱は長さ（L）が150mmで細長比 (L/D)は6.00である。 直径 $45 \mathrm{~mm}$ の円柱は基本形状の長さが $186 \mathrm{~mm}$ で, この両 端にプラ仸少製の円柱端部を連結できるようにしてい る。3種類の円柱端部と基本形状の端部の組合せにより， 9通りの細長比を実現した。図2参照。但し, 円柱端部 は後から製作したため, 直径が基本模型のものより若 干小さく，約 $0.15 \mathrm{~mm}$ の段差が円周状に模型前後に存在 している。試験した模型と細長比の組合せを表1に示す。 気流と平行になる様に直径 $45 \mathrm{~mm}$ ，長さ $226 \mathrm{~mm}$ $(\mathrm{L} / \mathrm{D}=5.02)$ の円柱では模型後縁から $275 \mathrm{~mm}$ 下流（ $x$ 軸方 向）で後流の総圧損失量が上下方向（鉛直上方を $z$ 軸の 正とする。）と水平方向（ $y$ 軸として， $x, z$ 軸と共に右手 系をなす方向を $y$ 軸の正とする。）でそれぞれ対称にな る様に姿勢角を調整した。調整後の $y$ 軸と $z$ 軸方向の $u / U$ 分布を対称軸に関して鏡像となる $u / U$ 分布と共に図 3 に 描いた。 $y$ 軸と $z$ 軸に関して対称性が確保されたことを 確認した後, 最終的に後流断面での総圧損失を測り，等 高線が円形に近く，時間的平均流では軸対称流れが成

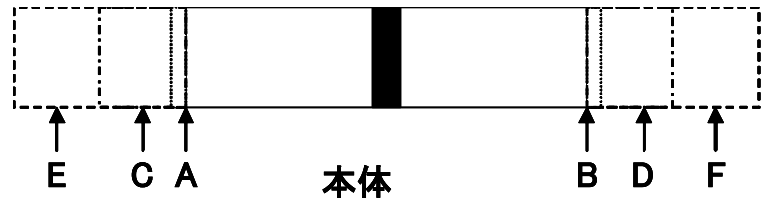

図 2 直径 $45 \mathrm{~mm} \phi$ 円柱模型組立図

(Figure 2 Setup of $45 \mathrm{~mm}$ diameter cylinder models)

表 1 抵抗測定試験に用いた模型 (Table 1 models used in the drag measurement tests)

\begin{tabular}{|c|c|c|c|}
\hline Model ID & $\begin{array}{c}\text { Diameter } \\
(\mathrm{mm})(\mathrm{D})\end{array}$ & $\begin{array}{c}\text { Fineness } \\
\text { ratio(L/D) }\end{array}$ & $\begin{array}{c}\text { Force Coefficient } \\
(\mathrm{A} / \mathrm{N})\end{array}$ \\
\hline$\# 25-0$ & 25 & 6.00 & 75.906 \\
\hline$\# 45-0$ & 45 & 4.13 & 39.234 \\
\hline$\# 45+\mathrm{B}$ & 45 & 4.58 & 39.304 \\
\hline$\# 45+\mathrm{A}+\mathrm{B}$ & 45 & 5.02 & 39.274 \\
\hline$\# 45+\mathrm{D}$ & 45 & 5.47 & \\
\hline$\# 45+\mathrm{B}+\mathrm{C}$ & 45 & 5.91 & 39.202 \\
\hline$\# 45+\mathrm{F}$ & 45 & 6.13 & 39.175 \\
\hline$\# 45+\mathrm{C}+\mathrm{D}$ & 45 & 6.80 & \\
\hline$\# 45+\mathrm{C}+\mathrm{F}$ & 45 & 7.47 & 39.293 \\
\hline$\# 45+\mathrm{E}+\mathrm{F}$ & 45 & 8.13 & 39.290 \\
\hline & & &
\end{tabular}

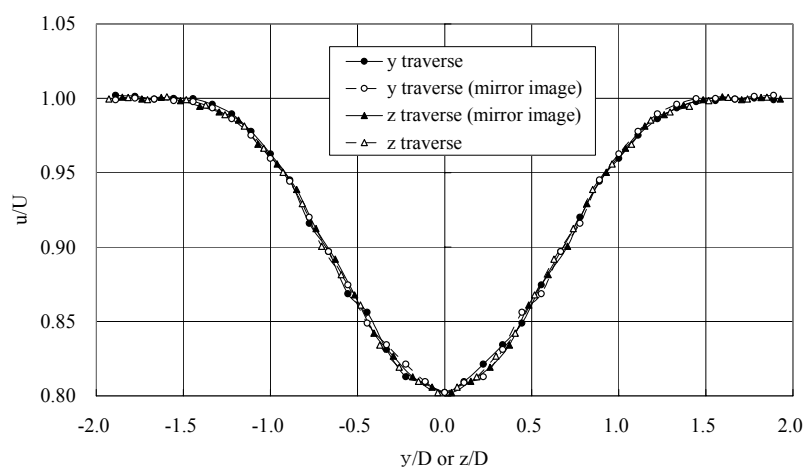

図3 $45 \phi$ 円柱後流y軸、 $z$ 軸に関する対称性 $(\mathrm{x} / \mathrm{D}=6.11)$

(Figure 3 Axial-symmetry of $u / U$ in the wake of a $45 \mathrm{~mm}$ diameter axial cylinder, $\mathrm{x} / \mathrm{D}=6.11$ )

立していることを確認した。図4に直径 $45 \mathrm{~mm}$ 円柱の後 流の $u / U$ 分布を示した。測定位置は円柱後端から $275 \mathrm{~mm}$ 下流位置である。図からほぼ軸対称流れが実現してい ることが伺える。

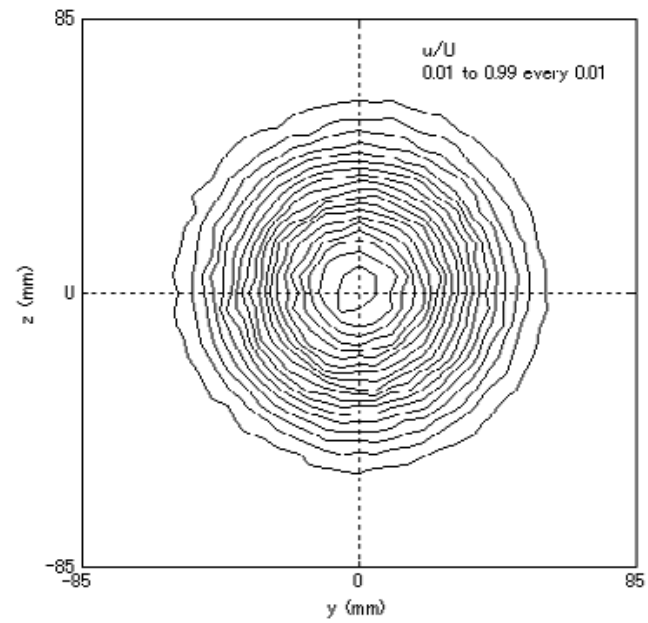

図 4 直径 $45 \mathrm{~mm}$ 円柱後流測定結果 $(\mathrm{x} / \mathrm{D}=6.11)$

(Figure $4 \mathrm{u} / \mathrm{U}$ distribution over wake of the $45 \mathrm{~mm}$ diameter cylinder, $\mathrm{x} / \mathrm{D}=6.11$ )

\section{2. 天秤較正と測定精度評価}

磁力支持天秤装置で抗力を測定するには, 試験模型 を用いて抗力較正試験を行う必要がある。試験は模型 の後端からナ㐰製の糸で，下流へ既知の重りで引き， この時の平均抗力コ价電流との関係を求めるものであ る。模型内部に入れている永久磁石が共通なので, 抗力 較正試験は総ての細長比の模型に対しては実施してい ない。計測した総てのケースで $0.2 \%$ 以内の誤差で一致して いる。表 1 にこの抗力較正試験結果も併せて示している。 測定した抗力係数に含まれる誤差はこの他に, 動圧測 定誤差，模型寸法誤差等がある。直径を基準長にした レイルズ数（一様流速 $\mathrm{U}$, 円柱直径 $D$, 動粘性係数 $v$ とす ると，レイルズ数 $\mathrm{Re}_{\mathrm{D}}$ は $U D / v$ と定義される。）が 100,000 
では抗力係数で \pm 0.005 の総誤差が見込まれた。詳細な 精度評価結果は付録Aを参照されたい。

\section{3. 磁力支持模型の運動の影響}

図5に細長比 6.13 円柱模型の $36.5 \mathrm{~m} / \mathrm{s}$ 気流中での支持状態 を示す。縦軸の一目盛りは $0.4 \mathrm{~mm}$ に相当していて, 位置変 動はほぼ士0.2mm以内に収まっていることが判る。風洞試 験中は無風時に比べて模型の運動は図に示す様に大き くなっているが，一定時間の平均量を取ることにより， こうした模型運動の影響を取り除くことが出来る。例 えば，一様流方向（ $x$ 軸）の運動を考え，ある時間間隔 (T)の時間平均を取ることを考えると, 磁力支持されて いる模型の運動方程式から，以下のような式を得る。

$$
\begin{aligned}
& m \cdot \ddot{x}=F_{m}+F_{\text {aero }} \\
& m \cdot \frac{\dot{x}(T)-\dot{x}(0)}{T}=\bar{F}_{m}+\bar{F}_{\text {aero }}
\end{aligned}
$$

ここで， $m$ は磁力支持模型の質量， $F_{m}$ と $F_{\text {aero }}$ はそれ ぞれ模型に作用する磁気力と空気力の $x$ 方向成分を示 す。また $F$ の上付横棒は時間 $T$ 間の平均量を表す。この 式から $x$ 方向の模型速度成分が小さければ，平均時間間 隔を十分長くすることにより，模型の運動の影響を小 さくできることを示している。こうした条件を満たせ ば，模型の運動が観測されても，時間平均的には模型 が完全に静止している時と同様に磁気力と空気力が釣 合っていると見なせ, 平均コ隹電流から模型に作用する 平均空気力を評価できることを保証している。本試験 の場合は約8秒間の平均を取ることで, 模型の運動に伴 う抗力係数に含まれる誤差は 0.0006 と評価された。詳細 な定量的評価結果は付録Bを参照されたい。

\section{4. 抗力測定結果}

抗力測定試験は主に一様流風速 $(U)$ が約 $20 \sim 35 \mathrm{~m} / \mathrm{s}$ で 実施した。総ての抗力は測定部中心の動圧で無次元化 され, 浮力補正, 阻塞効果補正が施されている5)。

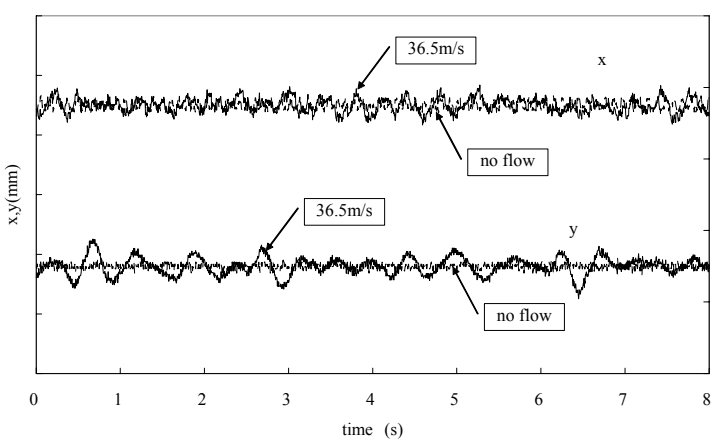

図5 模型位置姿勢の時間変化 $(0.4 \mathrm{~mm} / \mathrm{div})$

fineness ratio : 6.13 , flow speed $: 36.5 \mathrm{~m} / \mathrm{s}$

(Figure 5 Model position versus time)
直径 $45 \mathrm{~mm}$ 円柱の様々な細長比の場合で $\mathrm{Re}_{\mathrm{D}}$ に対して 抵抗係数を描いたものが図6である。較正試験で得られ た最大偏差他の誤差要因から推定した誤差量を図中に 誤差棒で示している。誤差範囲を考慮すると，この図 から $\operatorname{Re}_{\mathrm{D}}$ が60,000〜100,000の範囲では， $\operatorname{Re}_{\mathrm{D}}$ 依存性は認 められない。一方, 細長比依存性に関しては, 明らか に細長比が増大寸るにつれて抵抗係数も増加する傾向 が伺える。

取得データを $\mathrm{Re}_{\mathrm{D}}$ に関して内挿または若干外挿して $\mathrm{Re}_{\mathrm{D}}$

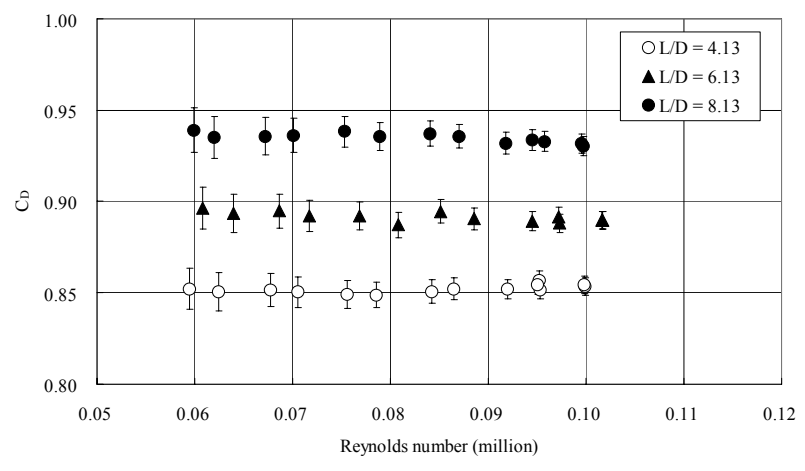

図6 抵抗係数のレイルバ゙数依存性

(Figure 6 Drag coefficient versus Reynolds number) が100,000での抗力係数を求め, 細長比との関係を図7 に描いた。その結果, 細長比 4.13 よりきい円柱の抵抗 係数は細長比の増加に比例して抵抗係数が増大し, そ の比率は約 0.0182 であった。

後に述べるように円柱前縁で剥離した流れは少なく とも約 $1.5 \mathrm{D}$ 以上下流で再付着し, 乱流境界層を形成し て下流へ流れていく。平板の乱流境界層の摩擦係数か ら再付着後の円柱表面の抵抗係数寄与分を評価して, 細長比に対する増加率を求めると，境界層の1/7乗則近 似 ${ }^{6)}$ 及び対数則近似 ${ }^{6)}$ ではどちらも0.0167という值を示 した。円柱全体の抵抗係数の細長比に対する増加率と, 平板乱流境界層の摩擦係数から評価した抵抗係数増加 率の間には若干の差異は残るが，前面及び底面圧力に

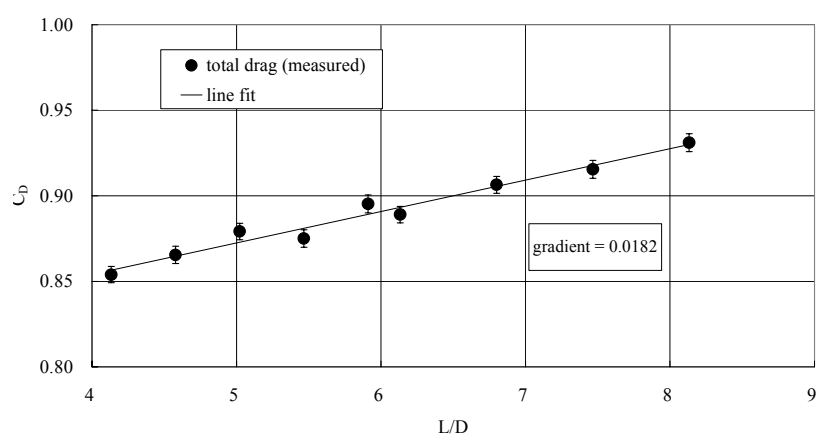

図7 抵抗係数の細長比依存性

(Figure 7 Drag coefficient versus fineness ratio) 
よる抵抗寄与分が一定と仮定すると, 細長比 $4.13 \sim 8.13$ の範囲における抵抗係数の細長比依存性は円柱長さの 増加に伴う境界層摩擦抵抗の増加によると言える。

\section{3. 後流計測}

直径 $25 \mathrm{~mm}$ 円柱の後流計測では, 後縁から10Dの位置 で後流断面の総圧を計測し抵抗係数を評価した。総圧 は一様流の静圧を基準とした圧力係数に変換した。

Betzの方法 ${ }^{7}$ により後流から抗力係数を評価した結果, 直径 $25 \mathrm{~mm}$ 円柱（細長比5）では磁力支持天秤装置で測 定した結果より約 $1.6 \%$ 小さく, 細長比 5.02 直径 $45 \mathrm{~mm}$ 円柱では約 $3 \%$ 小さい結果を得た。後流から抗力係数を 評価する場合は後流域の面積分となるため, $3 \%$ 程度の 差異の主な原因は後流動圧測定精度と数值積分の誤差 と考えられる。

直径 $45 \mathrm{~mm}$ 円柱の後流圧力損失を計測する際, ピトー 管とその支持棒が後流にどの程度影響するかを評価 するため, ピト一管を模型後縁から6.1D下流位置で, 後 流中心付近と後流外（中心から $90 \mathrm{~mm}$ 離れた位置）及 び，ピト管とその支持棒を外した時の3通りで, 円柱 抗力係数を測定し比較した。図8から判るように三者 は互いに誤差範囲内で同一值を取り, 後流測定用ピトー 管の影響は本試験精度では無視できた。

直径 $25 \mathrm{~mm}$ 円柱の後縁から $0.04 \mathrm{D}, 2 \mathrm{D}, 4 \mathrm{D}, 10 \mathrm{D}$ 下流の 4 点 で熱線プローブにより後流を横切る直線上の速度分布を 計測した結果を図9に示寸。更に, 変動成分のパワースペク 卜から2Dより下流で, 模型中心軸から直角方向に1D迄 広がる領域内では後流渦放出不听擞(渦放出周波数 $f$, 円柱直径 $D$, 一様流速 $U$ に対して㺪ローハ数は $f D / U$ で定義 される。）と思われる 0.185 程度に対応する周波数

$(238 \mathrm{~Hz})$ で変動成分のピークを観測した。但し, 総て の計測で観測は出来ていない。一方，10D下流では後流

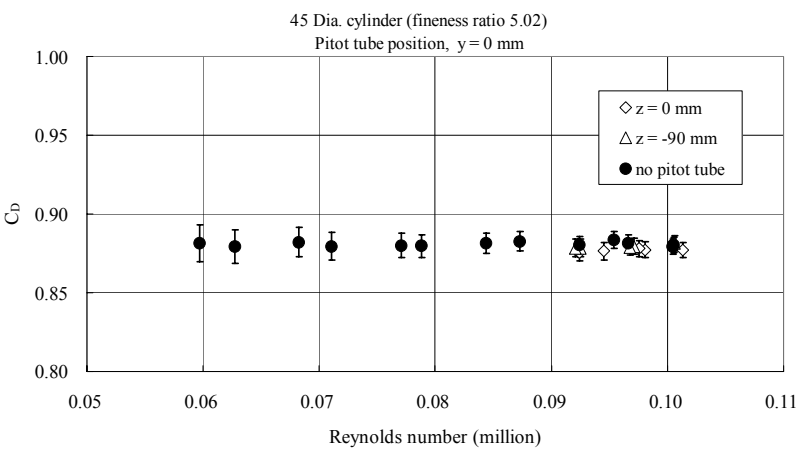

図8 後流測定用ピト-管の抗力係数への影響

(Figure 8 Drag coefficient versus Reynolds number, effect of a pitot tube for measuring pressure in wake)

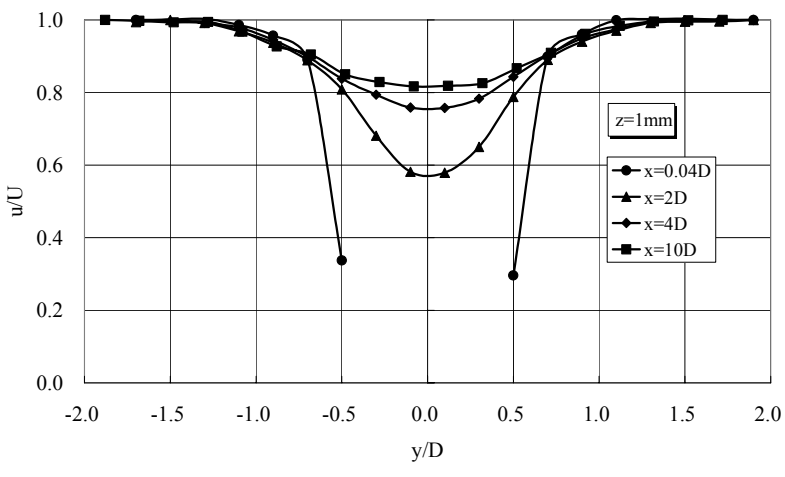

図9 直径 $25 \mathrm{~mm}$ 円柱後方の速度分布

(Figure 9 velocity distributions across the wake of $25 \mathrm{~mm}$ diameter cylinder)

の内の殆ど総ての観測位置でストーハル数を検出した。更 に, 後縁から $1 \mathrm{~mm}$ 下流では乱流境界層の特徵により低 周波変動成分のピークは観測できなかった。代表的な計 測例を図10に示す。直径 $45 \mathrm{~mm}$ 円柱でも，後縁から $1 \mathrm{~mm}$ 下流ではへルム机渦放出奴口ーハ数に対応する変動成分の ピークは観測されなかった。

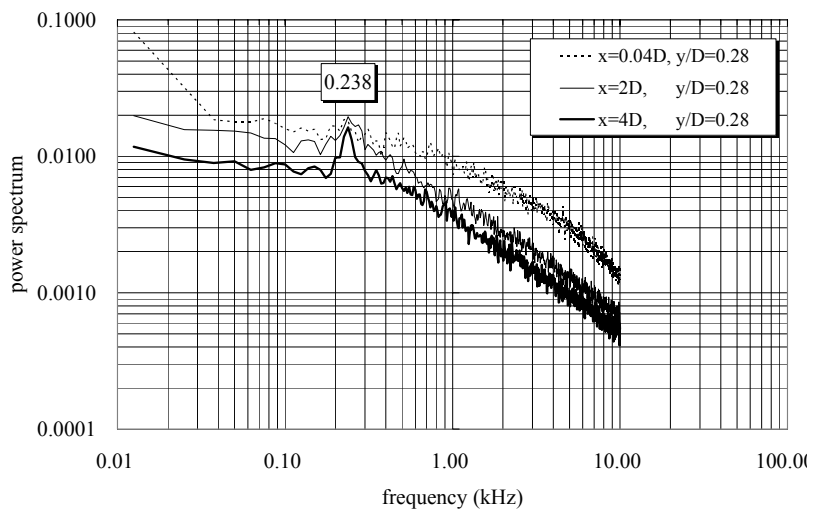

図 10 直径 $25 \mathrm{~mm}$ 円柱に於けるス卜ローハル数測定例

(Figure 10 Power density spectrum of velocity

fluctuations in the wake of the $25 \mathrm{~mm}$ diameter cylinder)

4. 後縁境界層測定結果

円柱後縁から $1 \mathrm{~mm}$ 下流位置で, 後流中心を通る水平 軸（ $y$ 軸）に沿って約1秒平均の速度分布と $40 \mathrm{~ms}$ 間の速 度変動を熱線プローブで測定した。図11，12には $y$ 軸に沿 つた平均速度比 $(u / U)$ 分布と速度変動比の $\mathrm{rms}$ 值 $\left(u_{r m s} / U\right)$ を4通りの細長比について描いた。直径 $25 \mathrm{~mm}$ 円柱の場 合は $\operatorname{Re}_{\mathrm{D}}$ が50,000, 直径 $45 \mathrm{~mm}$ 円柱の場合は 100,000 であ る。測定した平均速度分布から総ての細長比の円柱で, 後縁までには流れは平均的には円柱表面に付着してい る。但し, 細長比4.13の場合の速度分布は他のものに比 


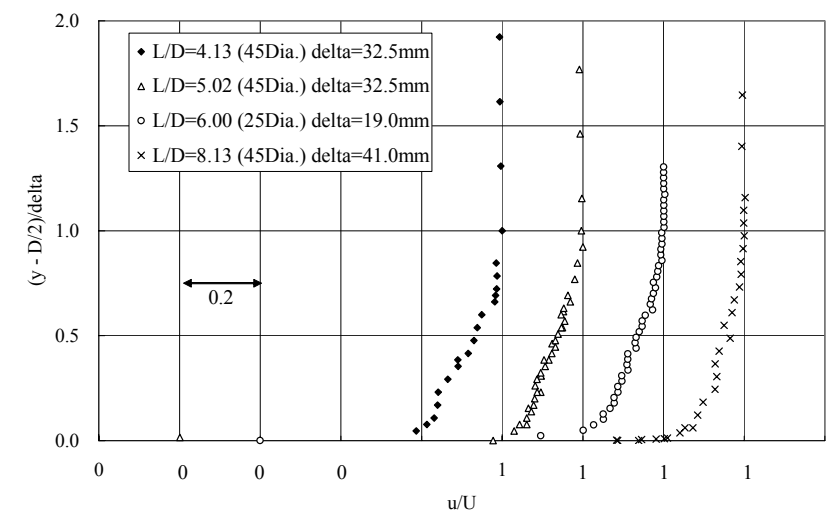

図11 平均速度分布の細長比依存性

(Figure $11\{\mathrm{y}-(\mathrm{D} / 2)\} / \delta$ versus $\mathrm{u} / \mathrm{U}$, effect of fineness ratio) ベて, $(y-D / 2) /$ deltaが 0.4 以下で速度欠損部分が大きい。 （delta：最大流速を得た模型表面からの高さ）また， 同じ領域で, 速度変動比の $\mathrm{rms}$ 值は細長比 4.13 で最も大 きく, 細長比が増すにつれて減少している。多少不均 一なプロファ价は短い平均時間のためと思われるが，円柱 上で測定したOta ${ }^{8)}$ らデータと比較すると, shape factor はL/Dが6以上では1.26となり，ほぼ合っている。別の 実験で一様流の乱流レベルは $0.1 \%$ 以下であった。図 $11 に$ 示した平均速度分布から運動量欠損に伴う抵抗係数寄 与分を評価し, 細長比に対して描き図13の○印で示す 結果を得た。完全な軸対称流れの場合, 抵抗係数は

$$
C_{D}=4 \frac{\theta}{R}-C_{p b} \quad \cdots
$$

となる (付録 $\mathrm{C}$ 参照)。ここで, $\theta$ は境界層の運動量厚 さ, $R$ は円柱の半径, $C_{p b}$ は円柱底面の平均圧力係数で あり, 円柱周りの圧力は一様流圧力と仮定している。こ の結果, 全体の抵抗(total drag)は運動量欠損に伴う抵抗 と底面に作用する圧力抵抗（base drag）の和で近似で きる。更に，運動量欠損に伴う抵抗は円柱前面にかか る圧力抵抗 (forebody pressure drag) と円柱側面に作用

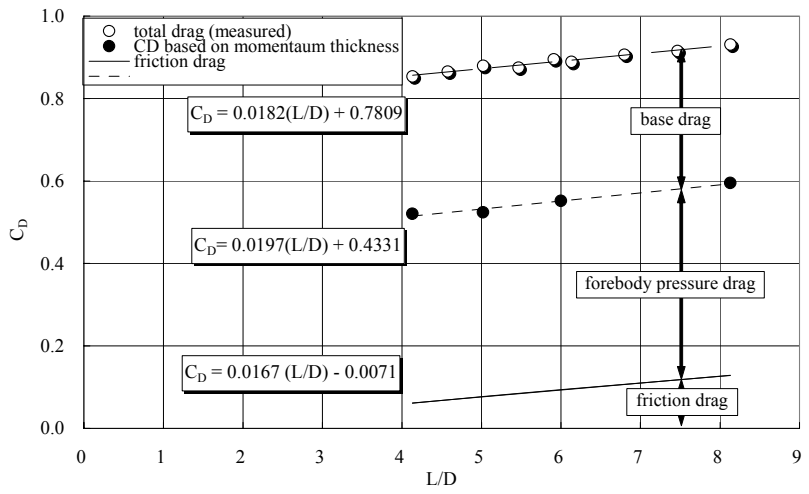

図13 運動量欠損に伴う抵抗係数の細長比依存性

(Figure 13 Drag coefficient based on momentum thickness versus fineness ratio)

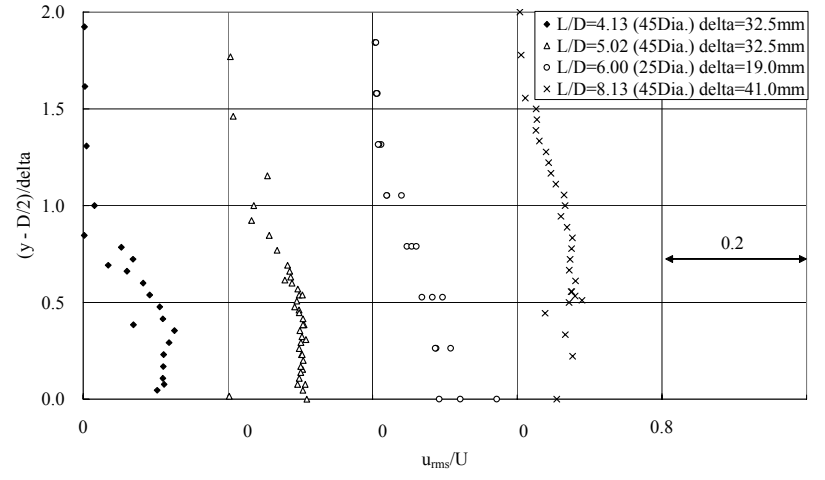

図12 速度変動のrms值と細長比の関係

(Figure $12 \mathrm{y} / \mathrm{D}$ versus $\mathrm{u}_{\mathrm{rms}} / \mathrm{U}$, effect of fineness ratio)

する摩擦抵抗(frinction drag)の和となる。図13には, 磁 力支持天秤で測定した全体の抵抗係数, 模型後端での 境界層速度分布測定結果から求めた運動量欠損に伴う 抵抗係数, 再付着位置を $1.5 \mathrm{D}$ とてその後対数速度分 布則に従う乱流境界層となった場合の摩擦抵抗の計3 種類の抵抗係数を描いた。この結果, 3 種の抵抗係数の 円柱細長比に対する増加率は互いに近い值であること が判った。また，付録Cに示すように底面抵抗は底面の 圧力係数で近似的に決まるので, 図13から底面圧力係 数は約- 0.35 である。レイルズ数が $10^{5}$ 付近で磁力支持を用 いた支持干渉無しの球の背圧係数測定結果では約 -0.40 という報告があり ${ }^{12)}$ ，この值は合理的と考えられる。 これらのことから, 円柱前面にかかる圧力抵抗係数と 底面抵抗係数は共に細長比に無関係にほぼ一定である と言える。

直径 $45 \mathrm{~mm}$ 円柱をステイグ支持し, 流速約 $30 \mathrm{~m} / \mathrm{s}$ でオイルロ 一により表面流れを可視化した結果を図14に示す。図か ら模型前縁から再付着位置までの長さを測った結果, その長さはおおよそ1.6D〜1.7Dであった。文献3)では

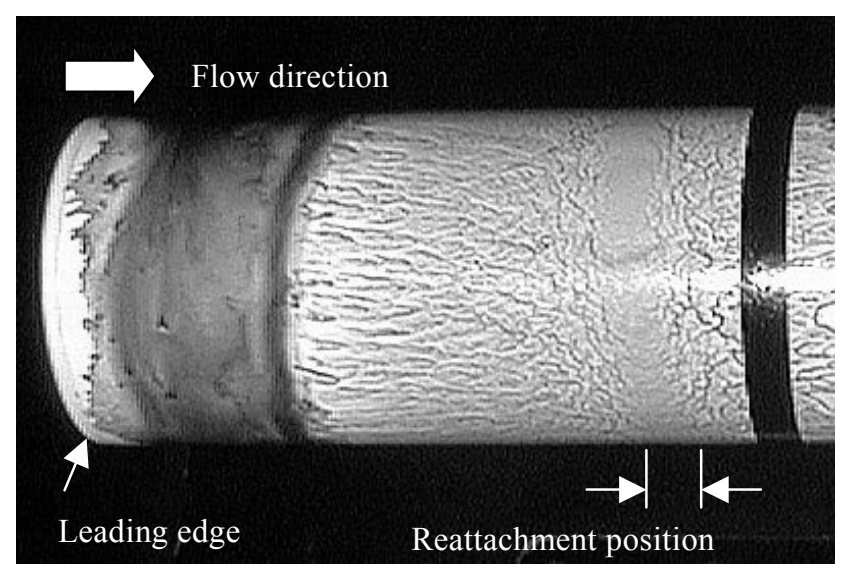

図14オイルフローによる円柱表面流れの可視化結果

(Figure 14 Flow pattern on $45 \mathrm{~mm}$ diameter cylinder by oil-flow visualization) 
再付着位置は1.5D と記されていて，これに近い結果で ある。差異は一様流乱れレベルやレイルズ数の違いが影響 したと考えられ，今後のさらなる考察予定項目である。 十分に発達した乱流境界層による後流の形成では, 摩 擦抵抗に細長比の影響が主に反映されていて, 底面圧 の抗力寄与は一定と考えられる。この結果, 細長比 4.13 以上では, 抵抗係数の細長比に対する増加率が一定で, 乱流境界層による細長比に対する摩擦抗力の寄与分の 抗力倸数増加率が実験值にほぼ近い值となったものと 考えられる。

\section{5. 既存データとの比較}

細長比変化に対する抵抗係数の変化について, 本試験 結果と共に文献1),2)のデータを図15に示す。図から判る ように, Hoernerに引用されたEiffelのデータは細長比が4 以上では抗力係数が増加していない。一方, Roberson のデータは細長比 8 で抗力係数は 0.99 を示している。本試 験結果は細長比4付近では両者の結果とほぼ同じであ るが，それより大きな細長比では両者と異なった值を 取っている。既に記したように, 本試験の抗力係数測 定誤差は \pm 0.005 程度である。また，円柱の姿勢は後流 を計測することで一様流に平行に調整されている。な お，付録 $\mathrm{D}$ に示寸様に，別の試験により同じ円柱が姿勢 角 $0.6^{\circ}$ だけ変化すると細長比 8 付近で抗力係数は高々 約 0.01 増加する程度であることを確認している。また更 に, 本試験結果は磁力支持により円柱を支持していて, 支柱干渉は存在しない。細長比8付近でのRobersonのデ 一夕と本試験結果との差量は0.06あり, 測定誤差では説明 できない。また, 姿勢角の違いで説明するにはその差 異は余りにも大きい。このことから, 細長比8の

Robersonのデータには模型支持方法の違いが現れた可能 性があるものと考えられる。

一方, Hoernerが引用しているEiffelのデータ（参考文献

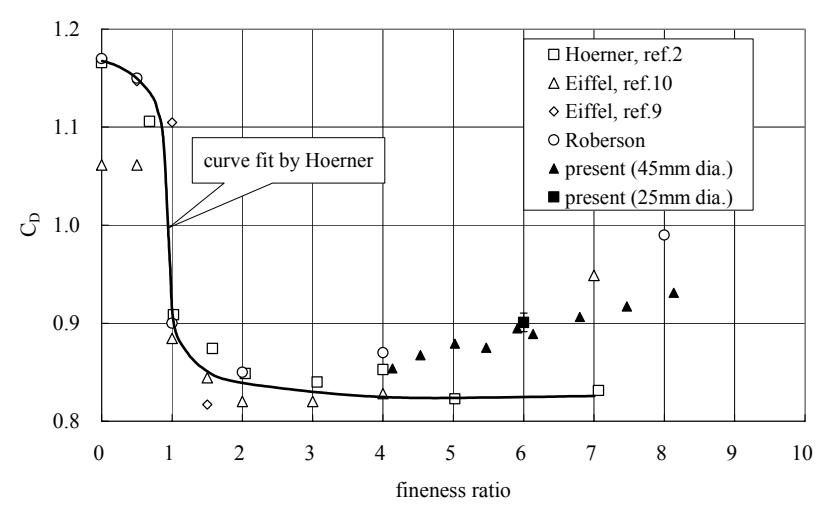

図15 円柱細長比に対する抗力係数変化
2）の図21）は抗力係数が細長比 4 以上では細長比に依 存しない傾向を示している。本試験結果は図15からも （詳細には図7から）, 明らかに細長比依存性を示して いる。HoernerはEiffelの1907年のレポートを参照したよう であるが，1907年の原典とは一致していない9”。Eiffel の1913年の風洞実験のレポート ${ }^{10)}$ を見ると細長比依存性 が出ている。摩擦抵抗を推測し差し引いたと思われる が，前者はよく引用されている事も鑑み，注意が必要 である。

6. まとめ

気流と平行な姿勢の円柱抵抗を幾つかの細長比 (4.13-8.13)について，JAXA60cmMSBSを用いて支持干 涉の無い状態で試験を実施し, 以下のことが判った。

$\checkmark$ 直径を代表長にしたレイルズ数で50,000〜100,000で は円柱の抵抗係数にレイルズ 数依存性は無い。

$\checkmark$ 細長比4.13以上では, 円柱前縁で剥離した流れは, 1.5D以上下流で再付着し, その下流の円柱表面で 乱流境界層が発達し, 後縁に達している。

$\checkmark$ 細長比4.13以上での円柱抗力係数の細長比依存性 は, 細長比増大による円柱長さの増加に伴う円柱 表面に発達した乱流境界層の摩擦抵抗増加が主な 原因である。

あとがき

本研究は平成 15 年度科学研究費補助金により実施 された。

参考文献

1. J. A. Roberson and C. T. Crowe : "Engineering Fluid Mechanics," $6^{\text {th }}$ edition, John Wiley \& Sons, Inc., 1997

2. S. F. Hoerner : "Fluid-Dynamic Drag", published by author, 1958, pp.3-12

3. K. Koeing and A. Roshko : "Study of Geometrical Effects on the Drag and Flow Field of Two Bluff Bodies Separated by a Gap,” J. Fluid Mech. Vol. 156, 1985, pp.167-204

4. 澤田秀夫, 国益徹也：「低速風洞用 $60 \mathrm{~cm}$ 磁力支持装 置の開発」, 日本航空宇宙学会論文集, 第50巻, 第 580号，pp.188-195，2002年5月号

5. Pankhurst,R.C. and Holder,D.W. :"Wind-Tunnel Technique", SIR ISAACPITMAN \& SONS,LTD., 1952, pp.340-349

(Figure 15 Drag coefficient versus fineness ratio) 
6. H.Schlichting,"Boundary-Layer Theory", $6^{\text {th }}$ edition, McGraw-Hill, pp.596-606, 1968

7. 岡本哲史：「応用流体力学」, 誠文堂新光社, 1968, pp. $260-262$

8. T. Ota,"An Axisymmetric Separated and Reattached Flow on a Longitudinal Blunt Circular Cylinder” Journal of Applied Mechanics, June 1975, pp. 311-315.

9. G. Eiffel," Recherches Expérimentales sur la Résistance de l'Air Exécutées à la Tour Eiffel, ” L. Maretheux, Impimeur, 1907

10. G. Eiffel: "The Resistance of the Air and Aviation," (translated by J. C. Hunsaker), London: Constable Co., Boston: Houghton, Mifflin \& Co. 1913

11. 澤田秀夫, 国益徹也, 須田信一：「航技研 $60 \mathrm{~cm}$ 磁力 支持天秤装置を用いた球形模型の抗力測定」，日本 風工学論文集, Vol.98, 2004.1号

12. 澤田秀夫, 国益徹也, 須田信一, 御簾納徹 : 「支持 干渉の無い球の背圧測定結果」, 日本風工学会誌, Vol.99, 2004.2号

\section{付録 $\mathrm{A}$ 抗力係数精度評価}

抗力係数の誤差評価では参考文献11）に記載されてい る磁力支持天秤装置の誤差評価方法を用いた。但し, 誤 差評価式において本試験レイルズ数範囲での近似的な $\mathrm{C}_{\mathrm{D}}$ 值として0.9を採用した。この結果, 円柱直径を代表長 としたレイルズ数が 100,000 の時，約 $0.8 \%$ の誤差が予測さ れる。図6,7,8にはこの誤差評価結果を誤差棒で示して いる。また，本試験のレイルバ数範囲の誤差は図A-1に示 す様にほぼ1\%以下であることが期待できる。

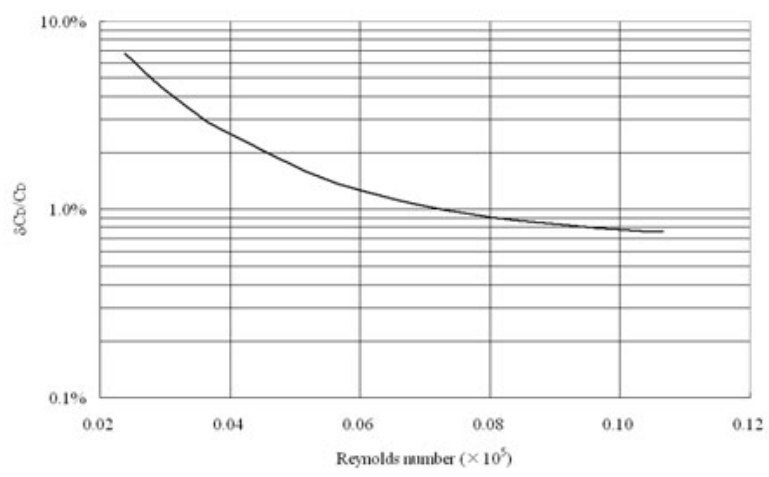

図A-1 直径 $45 \mathrm{~mm}$ 円柱模型の䛊差評価結果

(Figure A-1 Drag coefficient error evaluation result of a $45 \mathrm{~mm}$ diameter cylinder)

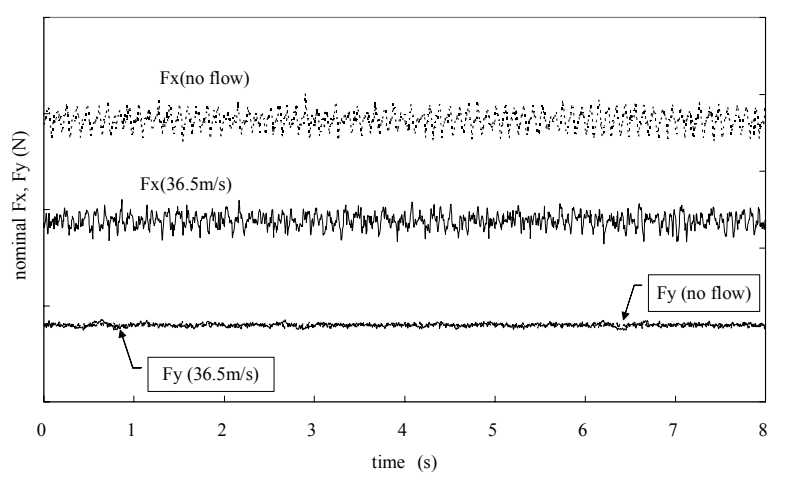

図B-1 模型に作用する磁気力の時間変化（1N/div）

(Figure B-1 Nominal magnetic force versus time)

付録B 模型位置姿勢変動の平均抗力への影響と非定常 空気力について

模型に作用する磁気力は，模型を磁力支持する制御用 コ隹電流から力較正試験結果を基に評価出来る。磁力支持 されている模型には重力, 磁気力の他に, 気流中では空気 力が作用している。模型が空中に一定の位置姿勢で静止し ている場合は, 全体としてこれらの外力は釣合い状態にあ る。実際には, 模型は完全に静止状態にないので, 平均加 速度が十分小さくなるように, 或る時間間隔で平均を取る。 その結果，外力の時間平均值も十分小さくできる。図5の 支持模型の質量は $1.455 \mathrm{~kg}$ である。抗力の場合， $x$ 座標測定 值を $25 \mathrm{~Hz}$ のローパスフィルターに通した後，8秒間の平均加速度は $0.0005 \mathrm{~m} / \mathrm{s}^{2}$ となり, 平均外力は最大で $0.0007 \mathrm{~N}$ となる。これ は抗力係数で 0.0006 の誤差に対応し十分小さな值である。 8 秒間の抗力平均值を評価する場合は加速度の効果は無視 できることを意味している。同様に，y軸方向に加わる外 力 $\left(F_{y}\right)$ の 8 秒間平均值への加速度の効果は最大 $0.00008 \mathrm{~N} て ゙$ あった。図B-1は模型に作用している外力の成分の中，気 流方向の $F_{x}$ と気流に直角方向の $F_{y}$ が気流中と静止気体中 でどのように変わるかを示している。気流中では抗力に釣 合う磁気力が約 $1 \mathrm{~N}$ 発生している。磁気力成分 $F_{x}$ の変動は 大きいが，静止気体中での $F_{x}$ も同様に大きく，この変動力 は流体に起因したものでない。一方， $F_{y}$ の時間履歴では平 均的に静止気体中の $F_{y}$ と同じ值を示している。また， $F_{y}$ では最大で $0.06 \mathrm{~N}$ 程度の制御磁気力を示している。この結 果, 気流に直角方向の非定常空気力は高々 $0.06 \mathrm{~N}$ 程度の磁 気力の大きさであることが伺える。実際に $0.1 \mathrm{~N}$ 以下の非定 常空気力を推定するには, 模型位置の更に高精度な計測, コイル電流と模型位置の測定結果間での位相のずれを補償す るデータ処理等の計測技術が求められる。 
付録 $\mathrm{C}$ 軸対称流れの抵抗係数評価

ここで考える物体は一様流に平行に置かれた直径D, 長さLの円柱とする。よって, 流れは軸対称である。検査 面Aとして, 円柱から十分上流で円柱中心軸を共有する円 盤とその円周を通過する流線が円柱後縁面と接する同じ 程度の大きさの円盤と交差する線で囲まれた円盤状の平 面，これら2つを連結する流線で構成される円筒面状の曲 面から成る閉曲面を採用する。

十分上流の円盤の検査面部分を $\mathrm{A}_{0}$, 円柱後縁に接する 円盤の検査面を $\mathrm{A}_{1}$, 円筒状の面を $\mathrm{As}$ と名づける。 $\mathrm{A}_{1}$ では 速度は至る所一様流流速で一定である。また，As上では 圧力は静圧に一致している。よって, 円柱に作用する抵抗 (D)は以下のようになる。

$$
\begin{aligned}
D= & \int_{A_{0}} \rho U^{2} d A+\int_{A_{0}} p_{\infty} d A \\
& -\int_{A_{1}} \rho u^{2} d A-\int_{A_{1}} p d A-\int_{A_{s}} p_{\infty} n_{x} d A
\end{aligned}
$$

ここで， $\rho$ は気体密度，uはx軸方向の局所速度成分， $p_{\infty}$ は一様静圧, $p$ は局所静圧, $n_{x}$ は検查面法線方向ベ外ルの $x$ 方向成分を表す。連続の式を考慮して(C-1)を変形すると，

$$
\begin{aligned}
& D=\int_{A_{1}} \rho u\left(U_{\infty}-u\right) d A-\int_{A_{1}} p d A \quad \ldots \quad(\mathrm{C}-2) \\
& +\int_{A_{0}} p_{\infty} d A-\int_{A_{s}} p_{\infty} n_{x} d A
\end{aligned}
$$

となる。更に, 抗力係数 $\mathrm{C}_{\mathrm{D}}$ に直して軸対称流れであるこ とを考慮する。円柱中心軸を $x$ 軸として, 軸からの距離を $r$ とすると, (C-2)式の円盤上の積分は,

$C_{D}=\frac{4}{R^{2}} \int_{0}^{R \infty}\left\{\frac{u}{U_{\infty}}\left(1-\frac{u}{U_{\infty}}\right)\right\} r d r-\frac{2}{R^{2}} \int_{0}^{R_{\infty}} C_{p} r d r \cdots(\mathrm{C}-3)$

ここで， $R_{\infty}$ は円盤状の検査面の半径であり，十分大きい 值である。運動量厚さ $\theta$ を導入すると,

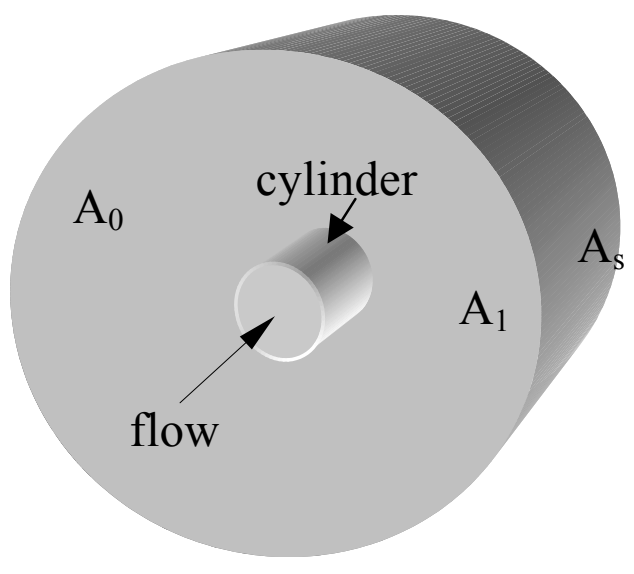

図C-1 気流に平行な円柱周りに設けた検査面 $\boldsymbol{A}$

(Figure C-1 Control volume $\boldsymbol{A}$ surrounding a cylinder parallel to flow)

$$
C_{D}=4\left(\frac{\theta}{R}\right)-C_{p_{b}}-\frac{2}{R^{2}} \int_{R}^{\infty} C_{p} r d r \quad \cdots \quad(\mathrm{C}-4)
$$

ここで, 積分の上限をの印で記した。この意味は $C_{p}$ が十分 ○になる地点までの積分であることを示す。円柱周りの流 れの静圧が円柱後端で一様流静圧に一致していると近似 できる場合は(2)式になる。

\section{付録D 模型姿勢角の抗力係数への影響}

気流に対する模型の姿勢角がどの程度抗力係数へ影響 するかを調べた。後流形状が軸対称になるように調整し， 円柱がその姿勢の時を, 気流に対して平行に円柱が設置さ れているとして, その姿勢からの変化角を円柱が気流に対 して傾いている角度とした。気流に対して0.6度だけ傾い た姿勢の時の円柱の抗力係数をその細長比に対してプロ ットしたものが図C-1である。抵抗係数の差異としては, 気流に対して円柱が傾いている時のほうが-0.001から 0.008だけ大きな抵抗係数を示したが，誤差棒の範囲内の 差異以内であり，有意な差としては認められなかった。

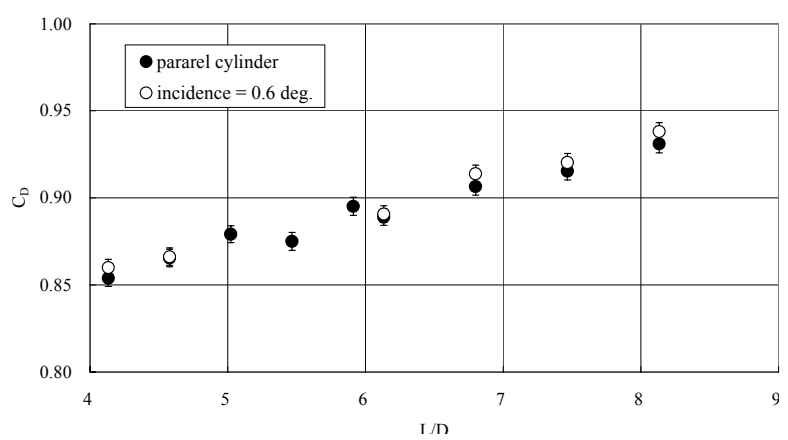

図D-1 直径 $45 \mathrm{~mm}$ 円柱抵抗係数への姿勢効果

(Figure C-1 Drag coefficient versus fineness ratio, effect of model attitude) 